\title{
Post Cholecystectomy Gossypiboma Mimicking a Liver Hydatid Cyst: Comprehensive Literature Review
}

\author{
Yusuf Yagmur ${ }^{1}$; Sami Akbulut ${ }^{2, *}$; Serdar Gumus ${ }^{1}$ \\ ${ }^{1}$ Department of Surgery, Diyarbakir Education and Research Hospital, Diyarbakir, Turkey \\ ${ }^{2}$ Department of Surgery, Liver Transplantation Institute, Faculty of Medicine, Inonu University, Malatya, Turkey \\ ${ }^{*}$ Corresponding Author: Sami Akbulut, Department of Surgery, Liver Transplantation Institute, Faculty of Medicine, Inonu University, P. O. Box: 44280 , Malatya, Turkey. \\ Tel: +90-4223410660, Fax:+90-4223410036, E-mail: akbulutsami@gmail.com \\ Received: July 13, 2014; Revised: September 25, 2014; Accepted: March 25, 2015
}

\begin{abstract}
Background: Gossypiboma is the term for forgotten textile products such as a surgical sponge and compress in the body cavity after a surgical procedure.

Objectives: The aim of this study was to evaluate previously published articles related to post cholecystectomy gossypiboma.

Materials and Methods: We conducted a systematic search using PubMed, Medline, Google and Google Scholar on post cholecystectomy gossypiboma. The keywords used were: gossypiboma and cholecystectomy, textiloma and cholecystectomy and post cholecystectomy gossypiboma. Furthermore, we also present a new case of post cholecystectomy gossypiboma.

Results: A total of 32 articles concerning 38 patients with post cholecystectomy gossypiboma that met the aforementioned criteria were included. Detailed intraoperative findings and surgical management were provided. The patients were aged from 26 to 79 years (Mean \pm SD: $47 \pm 13.6$ years); 32 were female and six were male. The time from the causative operation to presentation with a retained surgical sponge ranged from one to 480 months (Mean \pm SD: $56.5 \pm 93.5$ months).

Conclusions: Gossypiboma may not be symptomatic for many years or could be symptomatic for a short duration of time. Besides being a rare surgical complication, gossypiboma can lead to serious morbidity and mortality that may cause medico-legal problems. Diagnosis with imaging methods is difficult.
\end{abstract}

Keywords: Cholecystectomy; Surgical Sponges; Cysts, Hepatic Hydatid

\section{Background}

Gossypiboma, also known as retained foreign body, is an uncommon but serious complication following surgical interventions (1-5). Gossypiboma is used to describe a retained surgical sponge in the body compartment after surgery. This complication is frequently reported after abdominopelvic surgery, yet it can occur following any surgical procedure including thoracic, orthopedic, urological and neurosurgical procedures (1-8). The most important risk factors for retained foreign body are emergency surgery, unplanned change in the operation, and high body mass index. Clinical symptoms both in the early postoperative period as well as in the months or years following the initial surgery are often nonspecific (1, 9-14). Most clinical symptoms are depend on the sponge location, foreign body reaction and relationship between sponge and adjacent organs such as duodenum, stomach, intestine and liver.

\section{Objectives}

The primary aim of this study was to analyze cases of post cholecystectomy gossypiboma published in the medical literature before the 10th of July 2014. The secondary aim was to report a case of a 41-year-old female patient who was diagnosed with post-cholecystectomy gossypiboma.

\section{Materials and Methods}

We conducted a systematic literature search of PubMed, Medline, Google Scholar and Google databases using the following term, surgical sponge and cholecystectomy, gossypiboma and cholecystectomy, textiloma and cholecystectomy, and post cholecystectomy gossypiboma (alone or in different combinations). All identified abstracts, case reports, letters to the editor, review articles, original articles, and other documents were reviewed. The publication language was not an exclusion criterion, and studies published before 10th of July 2014 were included. Reference lists of the retrieved articles were also examined to identify citations that complied with our inclusion criteria. Corresponding authors of the articles were contacted by email to obtain more detailed information about the patients. Articles without an accessible full-text version or those providing insufficient information or insufficient data for comparison with other studies were excluded. Table 1 presents the following information: first author surname, year of publication, age, sex, initial surgery, interval between surgery and diagnosis (months), preliminary diagnosis, intraoperative findings and surgical approaches.

Copyright ( ) 2015, Iranian Red Crescent Medical Journal. This is an open-access article distributed under the terms of the Creative Commons Attribution-NonCommercial 4.0 International License (http://creativecommons.org/licenses/by-nc/4.0/) which permits copy and redistribute the material just in noncommercial usages, provided the original work is properly cited. 
Table 1. Summary of Thirty-two Articles Related to Gossypiboma Following Cholecystectomy in the Literature Published Between January 2000 and July 2014

\begin{tabular}{|c|c|c|c|c|c|c|c|c|}
\hline References & Year & Age & Gender & Initial Surgery & $\begin{array}{c}\text { Interval, } \\
\text { mon }\end{array}$ & $\begin{array}{c}\text { Preliminary } \\
\text { Diagnosis }\end{array}$ & Surgery & Intraoperative Findings \\
\hline Lv et al. (3) & 2014 & 61 & M & Cholecystectomy & 10 & Gossypiboma & $\begin{array}{l}\text { Sponge was removed and } \\
\text { the penetrated ulcer was } \\
\text { repaired with duodenor- } \\
\text { rhaphy }\end{array}$ & $\begin{array}{l}\text { Sponge migrated to the } \\
\text { duodenum }\end{array}$ \\
\hline Sistla et al. (4) & 2014 & 37 & $\mathrm{~F}$ & Cholecystectomy & 5 & Gossypiboma & $\begin{array}{c}\text { Fistula excision + primary } \\
\text { duodenal repair + feeding } \\
\text { jejunostomy }\end{array}$ & $\begin{array}{l}\text { Sponge migrated to the } \\
\text { duodenum Duodenocolic } \\
\text { fistula }\end{array}$ \\
\hline Aljehani et al. (5) & 2013 & 36 & $\mathrm{~F}$ & Cholecystectomy & 48 & Sterile abscess & $\begin{array}{l}\text { Complete excision + drain- } \\
\text { age }\end{array}$ & $\begin{array}{c}\text { Gossypiboma mimicking } \\
\text { cystic lesion }\end{array}$ \\
\hline Kohli et al. (6) & 2013 & 35 & $\mathrm{~F}$ & Cholecystectomy & 2 & $\begin{array}{l}\text { Gastro-cutaneous } \\
\text { fistula }\end{array}$ & $\begin{array}{l}\text { Sponge was removed with } \\
\text { gastric wall repair + feeding } \\
\text { jejunostomy }\end{array}$ & $\begin{array}{l}\text { Gastro-cutaneous fistula } \\
\text { sponge migrated to the } \\
\text { stomach }\end{array}$ \\
\hline Mostafa and Elsani (7) & 2013 & 42 & $\mathrm{~F}$ & Cholecystectomy & 6 & $\begin{array}{l}\text { Gastric outlet } \\
\text { obstruction }\end{array}$ & $\begin{array}{l}\text { Sponge was removed with } \\
\text { gastrostomy }\end{array}$ & $\begin{array}{l}\text { Sponge migrated to the } \\
\text { stomach }\end{array}$ \\
\hline Singhal et al. (8) & 2013 & 40 & $\mathrm{~F}$ & Cholecystectomy & 24 & $\begin{array}{l}\text { Intestinal ob- } \\
\text { struct. }\end{array}$ & $\begin{array}{c}\text { Sponge was removed with } \\
\text { enterotomy (ileum) }\end{array}$ & $\begin{array}{l}\text { Sponge migrated to the } \\
\text { small bowel }\end{array}$ \\
\hline Sozutek et al. (9) & 2013 & 52 & $\mathrm{~F}$ & $\begin{array}{l}\text { Cholecystectomy }+ \\
\text { T-tube drainage }\end{array}$ & 12 & $\begin{array}{l}\text { Gastric mass + } \\
\text { gossypiboma }\end{array}$ & $\begin{array}{l}\text { Sponge removed with gas- } \\
\text { troscopy without surgery }\end{array}$ & $\begin{array}{l}\text { Sponge migrated to the } \\
\text { stomach }\end{array}$ \\
\hline Shekhar et al. (10) & 2013 & 30 & $\mathrm{~F}$ & Cholecystectomy & 12 & $\begin{array}{l}\text { Gastric outlet } \\
\text { obstruction + } \\
\text { gossypiboma }\end{array}$ & $\begin{array}{l}\text { Distal gastrectomy + Billroth } \\
\text { II anastomosis }\end{array}$ & $\begin{array}{l}\text { Sponge migrated to the } \\
\text { stomach }\end{array}$ \\
\hline Aydogan et al. (11) & 2012 & 51 & $\mathrm{~F}$ & Cholecystectomy & 240 & $\begin{array}{l}\text { Intestinal ob- } \\
\text { struct. }\end{array}$ & $\begin{array}{l}\text { Sponge was removed with } \\
\text { enterotomy (ileum) }\end{array}$ & $\begin{array}{l}\text { Sponge migrated to the } \\
\text { small bowel }\end{array}$ \\
\hline Malhotra (12) & 2012 & 45 & $\mathrm{~F}$ & $\begin{array}{l}\text { Cholecystectomy + } \\
\text { hysterectomy }\end{array}$ & 30 & $\begin{array}{l}\text { Iatrogenic intesti- } \\
\text { nal perforation }\end{array}$ & $\begin{array}{l}\text { Ileal mass resected + end-to- } \\
\text { end ileoileal anastomosis. }\end{array}$ & $\begin{array}{l}\text { Sponge migrated to the } \\
\text { small bowel }\end{array}$ \\
\hline Erbay et al. (13) & 2012 & 63 & $\mathrm{~F}$ & Cholecystectomy & 48 & $\begin{array}{l}\text { Gossypiboma+ } \\
\text { gastric mass }\end{array}$ & $\begin{array}{l}\text { Sponge was removed with } \\
\text { gastric wall repair }\end{array}$ & $\begin{array}{l}\text { Sponge migrated to the } \\
\text { stomach }\end{array}$ \\
\hline Rizman et al. (14) & 2011 & 40 & $\mathrm{~F}$ & Cholecystectomy & 6 & $\begin{array}{c}\text { Gastric outlet } \\
\text { obstruction + } \\
\text { gastric mass }\end{array}$ & $\begin{array}{l}\text { Sponge removed with gas- } \\
\text { troscopy without surgery }\end{array}$ & $\begin{array}{l}\text { Sponge migrated to the } \\
\text { stomach }\end{array}$ \\
\hline Fragulidis et al. (15) & 2011 & 57 & M & $\begin{array}{l}\text { Cholecystectomy+ } \\
\text { appendectomy }\end{array}$ & 180 & Hydatid cyst & Complete excision & Subhepatic gossypiboma \\
\hline Duman et al. (16) & 2011 & 51 & $\mathrm{~F}$ & Cholecystectomy & 96 & Hydatid cyst & $\begin{array}{l}\text { Complete excision + PAIR for } \\
\text { hydatid cyst }\end{array}$ & $\begin{array}{l}\text { Four sponges found in } \\
\text { gossypiboma lesion }\end{array}$ \\
\hline Ray and Das (17) & 2011 & 54 & $\mathrm{~F}$ & Cholecystectomy & 84 & Gossypiboma & $\begin{array}{c}\text { Lesion was removed along } \\
\text { the adhered transverse } \\
\text { colon }\end{array}$ & Subhepatic gossypiboma \\
\hline Rajalingam et al. (18) & 2011 & 35 & $\mathrm{~F}$ & Cholecystectomy & 96 & $\begin{array}{l}\text { Gall bladder can- } \\
\text { cer + choledochal } \\
\text { cyst }\end{array}$ & $\begin{array}{l}\text { Completion of cholecystec- } \\
\text { tomy + choledochal cyst } \\
\text { excision + Roux-en-y hepati- } \\
\text { cojejunostomy + complete } \\
\text { excision of the gossypiboma }\end{array}$ & $\begin{array}{c}\text { Subhepatic gossypiboma } \\
\text { + choledochal cyst + } \\
\text { incomplete gall bladder }\end{array}$ \\
\hline Sozutek et al. (19) & 2010 & 64 & $\mathrm{~F}$ & $\begin{array}{l}\text { Cholecystectomy+ } \\
\text { surrenalectomy }\end{array}$ & 144 & $\begin{array}{l}\text { Complicated } \\
\text { hydatid cyst }\end{array}$ & $\begin{array}{l}\text { Complete excision + drain- } \\
\text { age }\end{array}$ & $\begin{array}{l}\text { Suprahepatic gossypi- } \\
\text { boma }\end{array}$ \\
\hline $\begin{array}{l}\text { Alegre-Salles et al. } \\
(20)\end{array}$ & 2010 & 48 & $\mathrm{~F}$ & Cholecystectomy & 24 & $\begin{array}{l}\text { Intestinal ob- } \\
\text { struct. }\end{array}$ & $\begin{array}{l}\text { Sponge was removed with } \\
\text { gastrostomy }\end{array}$ & $\begin{array}{l}\text { Sponge migrated to the } \\
\text { stomach }\end{array}$ \\
\hline Alayo et al. (21) & 2010 & 27 & $\mathrm{~F}$ & Cholecystectomy & 6 & $\begin{array}{l}\text { Microperforation } \\
\text { + foreign body }\end{array}$ & Nonsurgical management & $\begin{array}{l}\text { Sponge spontaneously } \\
\text { passed with the stool }\end{array}$ \\
\hline Ozyer and Boyvat (22) & 2009 & 58 & $\mathrm{~F}$ & $\begin{array}{l}\text { Partial cholecystec- } \\
\text { tomy }\end{array}$ & 4 & $\begin{array}{l}\text { Intestinal ob- } \\
\text { struct. }\end{array}$ & $\begin{array}{l}\text { Sponge removed with } \\
\text { sigmoidoscopy without } \\
\text { surgery }\end{array}$ & $\begin{array}{l}\text { Sponge migrated to the } \\
\text { colon }\end{array}$ \\
\hline Sharma et al. (23) & 2008 & 30 & $\mathrm{~F}$ & Cholecystectomy & 10 & Small bowel mass & Resection + anastomosis & Jejunocolic fistula \\
\hline Erdil et al. (24) & 2008 & 55 & $\mathrm{~F}$ & $\begin{array}{l}\text { Cholecystectomy } \\
\text { + PEG }\end{array}$ & 12 & $\begin{array}{l}\text { Gastrointestinal } \\
\text { bleeding }\end{array}$ & $\begin{array}{c}\text { Sponge was removed } \\
\text { with gastroscopy without } \\
\text { surgery }\end{array}$ & $\begin{array}{l}\text { Sponge migrated to the } \\
\text { duodenum }\end{array}$ \\
\hline
\end{tabular}


YagmurYet al.

\begin{tabular}{|c|c|c|c|c|c|c|c|c|}
\hline Kansakar et al. (25) & 2008 & 55 & $\mathrm{~F}$ & Cholecystectomy & 168 & Gossypiboma & Resection + anastomosis & $\begin{array}{l}\text { Sponge migrated to the } \\
\text { ileum and ileoileal fistula } \\
\text { occurred }\end{array}$ \\
\hline Agarwal et al. (26) & 2008 & 40 & $\mathrm{~F}$ & Cholecystectomy & 18 & $\begin{array}{l}\text { Intestinal ob- } \\
\text { struct. }\end{array}$ & $\begin{array}{l}\text { Sponge removed with } \\
\text { jejunal enterotomy }\end{array}$ & $\begin{array}{l}\text { Sponge migrated to the } \\
\text { jejunum }\end{array}$ \\
\hline \multirow[t]{2}{*}{ Sarda et al. (27) } & 2007 & 26 & $\mathrm{~F}$ & Cholecystectomy & $8 \mathrm{wk}$ & $\begin{array}{l}\text { Gastric outlet } \\
\text { obstruction }\end{array}$ & $\begin{array}{c}\text { Sponge was removed } \\
\text { with gastroscopy without } \\
\text { surgery }\end{array}$ & $\begin{array}{l}\text { Sponge migrated to the } \\
\text { stomach }\end{array}$ \\
\hline & & 32 & $\mathrm{~F}$ & $\begin{array}{l}\text { Cholecystectomy }+ \\
\text { tubal ligation }\end{array}$ & 4 & $\begin{array}{l}\text { Intestinal ob- } \\
\text { struct. }\end{array}$ & $\begin{array}{l}\text { Complete excision + adhe- } \\
\text { siolysis }\end{array}$ & $\begin{array}{l}\text { Sponge surrounded by } \\
\text { mesentery }\end{array}$ \\
\hline \multirow[t]{5}{*}{ Yildirim et al. (28) } & 2006 & 46 & $\mathrm{~F}$ & Cholecystectomy & 36 & Gossypiboma & Complete excision & Subhepatic gossypiboma \\
\hline & & 39 & M & Cholecystectomy & 27 & Gossypiboma & Complete excision & Subhepatic gossypiboma \\
\hline & & 71 & M & Cholecystectomy & 480 & Hydatid cyst & Complete excision & Subhepatic gossypiboma \\
\hline & & 64 & M & Cholecystectomy & 216 & Gossypiboma & Complete excision & Subhepatic gossypiboma \\
\hline & & 79 & $\mathrm{~F}$ & $\begin{array}{l}\text { Cholecystectomy+ } \\
\text { Choledocoduode- } \\
\text { nostomy }\end{array}$ & 1 & Abscess & Complete excision & Interloop gossypiboma \\
\hline \multirow[t]{2}{*}{ Tiwary et al. (29) } & 2005 & 35 & $\mathrm{~F}$ & Cholecystectomy & 3 & $\begin{array}{l}\text { Gastric outlet } \\
\text { obstruction }\end{array}$ & $\begin{array}{l}\text { Sponge was removed with } \\
\text { gastrostomy }\end{array}$ & $\begin{array}{l}\text { Sponge migrated to the } \\
\text { stomach }\end{array}$ \\
\hline & & 30 & $\mathrm{~F}$ & Cholecystectomy & 4,5 & $\begin{array}{l}\text { Gastric outlet } \\
\text { obstruction }\end{array}$ & $\begin{array}{l}\text { Sponge was removed with } \\
\text { gastrostomy }\end{array}$ & $\begin{array}{l}\text { Sponge migrated to the } \\
\text { stomach }\end{array}$ \\
\hline Ersoy et al. (30) & 2004 & 61 & $\mathrm{~F}$ & Cholecystectomy & 12 & Gossypiboma & Complete excision & $\begin{array}{c}\text { Gossypiboma mimicking } \\
\text { cystic lesion }\end{array}$ \\
\hline $\begin{array}{l}\text { Gencosmanoglu and } \\
\text { Inceoglu (31) }\end{array}$ & 2003 & 74 & $\mathrm{~F}$ & $\begin{array}{l}\text { Cholecystectomy+ } \\
\text { hernia repair }\end{array}$ & 36 & Gossypiboma & $\begin{array}{l}\text { Resection + anastomosis } \\
\quad \text { (jejunal segment) }\end{array}$ & $\begin{array}{c}\text { Sponge surrounded by } \\
\text { mesentery + Jejuno jeju- } \\
\text { nal fistula }\end{array}$ \\
\hline Puri et al. (32) & 2002 & 32 & $\mathrm{~F}$ & Cholecystectomy & 8 & $\begin{array}{l}\text { Intestinal } \\
\text { obstruct + gos- } \\
\text { sypiboma }\end{array}$ & $\begin{array}{l}\text { Resection + anastomosis } \\
\text { (jejunal segment) }\end{array}$ & $\begin{array}{l}\text { Sponge migrated to the } \\
\text { jejunum }\end{array}$ \\
\hline Manikyam et al. (33) & 2002 & 44 & $\mathrm{~F}$ & Cholecystectomy & 24 & $\begin{array}{l}\text { Gastric outlet } \\
\text { obstruction + } \\
\text { Bezoar }\end{array}$ & $\begin{array}{l}\text { Right hemicolectomy+ } \\
\text { duodenal repair }\end{array}$ & Duodeno-ileo-colic fistula \\
\hline Dux et al. (34) & 2002 & 47 & M & Cholecystectomy & 10 & Gossypiboma & $\begin{array}{l}\text { Resection + anastomosis } \\
\text { (jejunal segment) }\end{array}$ & $\begin{array}{c}\text { Sponge migrated to the } \\
\text { duodenum + duodenal } \\
\text { fistula }\end{array}$ \\
\hline
\end{tabular}

\section{Results}

\subsection{Literature Review}

A literature search using the above review criteria retrieved a total 32 articles on post-cholecystectomy gossypiboma. The studies involved 38 patients with postcholecystectomy gossypiboma: 32 patients were female and six patients were male, with ages ranging from 26 to 79 years (mean \pm SD: $47 \pm 13.6$ years). The time from the causative operation to presentation with a retained surgical sponge ranged from one to 480 months (mean \pm SD: $56.5 \pm 93.5$ months). Detailed intraoperative findings and surgical management are provided in Table 1.

\subsection{Case Report}

A 41-year-old female patient was admitted to our hospital with complains of occasional abdominal pain. She had undergone open cholecystectomy for cholelithiasis fifteen years ago. Physical examination revealed no significant findings apart from previous right subcostal surgical incision. On contrast-enhanced abdominal computed tomography; stages 4 - 5 hydatid cyst, about $8 \mathrm{~cm}$ in diameter, accompanied by calcification on subdiaphragmatic surface at segment 7 - 8 of the liver was detected (Figure 1). The patient underwent laparotomy with a preliminary diagnosis of hydatid cyst. After Adhesions secondary to previous operations were separated, the lesion located between the liver and diaphragm was detected. The lesion was aspirated with a veress needle and then filled with povidone iodine and povidone iodine embedded compress was placed around the lesion. When the lesion was opened, dark yellow abscess content was noticed and aspirated. A surgical compress or towel having partially corrupted fibrous structures was detected within the lesion (Figure 2). Lesions were 9-10 pieces with different sizes. All lesions were completely cleared. A drain was placed before terminating the operation. The drain was pulled out on the third postoperative day. The patient recovered without complications and remained well and symptom-free for at least 8 months after discharge. 


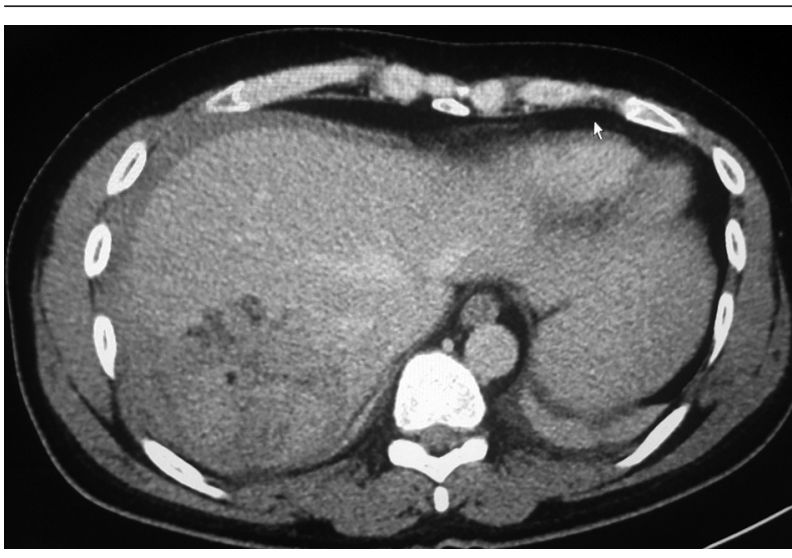

Figure 1. Contrast-Enhanced Abdominal Computed Tomography Showing a Large Cystic Mass (Hydatid Cyst) Lesion Located on the Subdiaphragmatic Surface at Segment 7 - 8 of the Liver

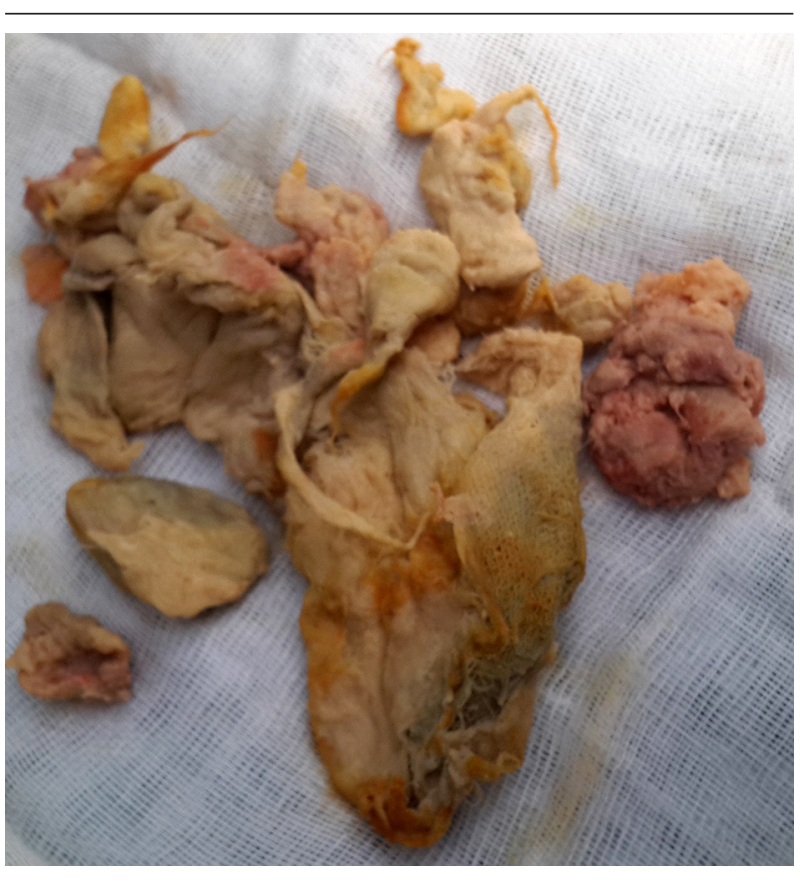

Figure 2. Postoperative View of Surgical Sponge Removed From Cystic Lesion Located on the Subdiaphragmatic Surface of the Liver

\section{Discussion}

Gossypiboma is a forgotten surgical material after surgery in the body that consists of non-absorbable textile products (1-5). The term "gossypiboma" is derived from the Latin term gossypium ("cotton wool, cotton") and the suffix boma (concealment). It was described by Wilson for the first time in 1884 (2). It is also called textiloma, gauzoma or muslinoma (3). Gossypiboma is a rare complication of surgery, but leads to serious medico-legal problems between patients and doctors and because of this, it should be considered important. Gossypiboma is most commonly seen after abdominopelvic cavities surgery, but it can also follow thoracic, orthopedic, urologi- cal and neurosurgical procedures $(2,4,33)$.

Clinical symptoms related to intra-abdominal gossypiboma are variable. While it may remain asymptomatic; it can present in a wide range of clinical statuses such as abdominal pain, nausea, vomiting, tenesmus, diarrhea, gastrointestinal hemorrhage, fistula formation, intestinal obstruction, gastric outlet obstruction, transmural luminal migration, visceral perforation, abscess or sepsis, in terms of radiological features $(13,14,26,35)$. Diagnosis is not possible with physical examination, laboratory test and radiologic tools. The most important factor that arouses suspicions is the patient's history of previous surgery.

Preoperative diagnosis is very difficult. Radiologic manifestations depend on sponge location, foreign body reaction and presence of a radiopaque marker (2). Correct preoperative diagnosis can be made for only onethird of cases (3). Radiological procedures such as X-ray, ultrasound, computed tomography, magnetic resonance imaging, barium enema studies and endoscopic instruments may be helpful (33). If the retained surgical swab is marked with radioactivity, diagnosis to locate is fairly easy by X-ray. As shown in the case presented in this study, it may lead to similar image interpretation as hydatid cyst. Due to the number of undetected asymptomatic cases and cases that are not reported because present malpractice laws lead to medico-legal problems, the true incidence of gossypiboma is not fully known. According to available statistics frequency of gossypiboma is one in 100 - 5000 surgical operations and one in 1000 - $1500 \mathrm{ab}$ dominal operations $(5,33)$. Fifty-two percent of cases have been seen after abdominal surgery, 22\% after gynecological surgery, $10 \%$ after urological/vascular surgery, and $6 \%$ after orthopedic/spinal surgery. Contrary to expectations, 30\% of reported cases are seen after emergency surgery, while 70\% were observed after elective surgery (3). Risk factors are obesity, emergency surgical operations and unplanned changes of the team $(1,6)$. The sponges are often forgotten surgical foreign bodies $(7,8)$. Sponges or compresses suck blood in a short time and their colors change and thus can be overlooked. While these textile products can give clinical findings as soon as possible, by an abscess, many remain sterile and become focus of granuloma and create a mass. Gossypiboma may cause transmural migration, perforate the visceral organs or lead to lumen obstruction (9). The treatment of gossypiboma, unquestionably, is by removal. In some patients, after cholecystectomy, transmutable migration of sponge to the stomach has been reported and some were removed endoscopically (10-13). Without distinction between elective or emergency surgery, sponges and compresses should be counted exactly. During surgery, care must be taken not to use small and unmarked tampons. Nurses should be warned to count sponges and compresses during nursing team changes. When closing the incision, the surgeon must be sure that all used sponges and compresses are counted. Before closing the surgical 
field in suspected cases, surgical fields should be checked carefully and marked sponges should be checked with radiography. As a result, for prevention of gossypiboma in surgery, all operating staff should pay attention to this preventable surgical complication.

\section{Acknowledgements}

The authors wish to thank Sami Akbulut for performing this literature review and designing the study.

\section{Authors' Contributions}

Study concept and design: Yusuf Yagmur and Sami Akbulut. Analysis and interpretation: Sami Akbulut. Drafting of the manuscript: Sami Akbulut and Serdar Gumus. Critical revision of the manuscript for important intellectual content:Yagmur and Sami Akbulut.

\section{References}

1. Akbulut S, Arikanoglu Z, Yagmur Y, Basbug M. Gossypibomas mimicking a splenic hydatid cyst and ileal tumor : a case report and literature review. J Gastrointest Surg. 2011;15(11):2101-7.

2. Yilmaz Durmaz D, Yilmaz BK, Yildiz O, Bas Y. A rare cause of chronic cough: intrathoracic gossypiboma. Iran J Radiol. 2014;11(2).

3. Lv YX, Yu CC, Tung CF, Wu CC. Intractable duodenal ulcer caused by transmural migration of gossypiboma into the duodenum-a case report and literature review. BMC Surg. 2014;14:36.

4. Sistla SC, Ramesh A, Karthikeyan VS, Ram D, Ali SM, Subramaniam RV. Gossypiboma presenting as coloduodenal fistula--report of a rare case with review of literature. Int Surg. 2014;99(2):126-31.

5. Aljehani Y, Albuainain H, Hassan K, Alshaya A. Gossypiboma Presenting as a Sterile Abscess. Bahrain Medical Bulletin. 2013;35(3):155-7.

6. Kohli S, Singhal A, Tiwari B, Singhal S. Gossypiboma, varied presentations: a report of two cases. J Clin Imaging Sci. 2013;3:11.

7. Mostafa HA, Elsani A. Retained Sponge After Open Cholecystectomy Causing Gastric Outlet Obstruction: Case Report And Literature Review. The Internet Journal of Surgery. 2013;30(2).

8. Singhal BM, Kumar V, Kaval S, Singh CP. Spontaneous intraluminal migration of gossypiboma with intestinal obstruction. $O A$ Case Reports. 2013;2:145.

9. Sozutek A, Yormaz S, Kupeli H, Saban B. Transgastric migration of gossypiboma remedied with endoscopic removal: a case report. BMC Res Notes. 2013;6:413.

10. Shekhar C, Kumar A, Chandra A. Transmural migration of surgical sponge into stomach with outlet obstruction: Gossypiboma. Indian J Gastroenterol. 2013;32(3):208.

11. Aydogan A, Akkucuk S, Yetim I, Ozkan OV, Karcioglu M. Gossypiboma causing mechanical intestinal obstruction: a case report. Case Rep Surg. 2012;2012:543203.

12. Malhotra MK. Migratory surgical gossypiboma-cause of iatrogenic perforation: case report with review of literature. Niger $J$ Surg. 2012;18(1):27-9.

13. Erbay G, Koc Z, Caliskan K, Araz F, Ulusan S. Imaging and clinical findings of a gossypiboma migrated into the stomach. TurkJ Gastroenterol. 2012;23(1):54-7.

14. Rizman F, Swaleh A, Ahmed F, Iqbal Z, Ahmed R. Gastric gossypiboma. PJR. 2011;21:27-9.
15. Fragulidis GP, Chondrogiannis KD, Karakatsanis A, Lykoudis PM, Melemeni A, Polydorou A, et al. Cystoid gossypiboma of the liver 15 years after cholecystectomy. Am Surg. 2011;77(1):E17-8.

16. Duman AE, Ersoy O, Abbasoglu O, Harmanci O, Aydinli M, Bayraktar Y, et al. Misdiagnosis of gossypiboma as hydatid cyst. Indian J Gastroenterol.2011;30(6):285.

17. Ray S, Das K. Gossypiboma presented as abdominal lump seven years after open cholecystectomy.J Surg Case Rep. 2011;2011(8):2.

18. Rajalingam R, Saluja SS, Sharma A, Mishra PK. Post cholecystectomy gossypiboma: a malignant masquerade. Am Surg. 2011;77(5):E94-5.

19. Sozutek A, Karabuga T, Bozdag AD, Derici H. [Asymptomatic gossypiboma mimicking a liver mass]. Ulusal Cerrahi Dergisi. 2010;26:225-8.

20. Alegre-Salles VJ, Saba E, Dias-Soares P. Clinical images in gastroenterology: Textiloma (Gossypiboma) in the gastric lumen. Rev Gastroenterol Mex. 2010;75(1):77.

21. Alayo E, Attar B, Go B. Image of the month. A case of recurrent abdominal pain due to a gossypiboma with spontaneous resolution. Clin Gastroenterol Hepatol. 2010;8(2):e13-4.

22. Ozyer U, Boyvat F. Imaging of a retained laparotomy towel that migrated into the colon lumen. Indian J Radiol Imaging. 2009;19(3):219-21.

23. Sharma D, Pratap A, Tandon A, Shukla RC, Shukla VK. Unconsidered cause of bowel obstruction-gossypiboma. Can J Surg. 2008;51(2):E34-5.

24. Erdil A, Kilciler G, Ates Y, Tuzun A, Gulsen M, Karaeren N, et al. Transgastric migration of retained intraabdominal surgical sponge: gossypiboma in the bulbus. Intern Med. 2008;47(7):613-5.

25. Kansakar R, Thapa P, Adhikari S. Intraluminal migration of Gossypiboma without intestinal obstruction for fourteen years. JNMA J Nepal Med Assoc. 2008;47(171):136-8.

26. Agarwal AK, Bhattacharya N, Mukherjee R, Bora AA. Intra luminal gossypiboma. PakJMed Sci. 2008;24:461-3.

27. Sarda AK, Pandey D, Neogi S, Dhir U. Postoperative complications due to a retained surgical sponge. Singapore Med J. 2007; 48(6):e160-4.

28. Yildirim S, Tarim A, Nursal TZ, Yildirim T, Caliskan K, Torer N, et al. Retained surgical sponge (gossypiboma) after intraabdominal or retroperitoneal surgery: 14 cases treated at a single center. Langenbecks Arch Surg. 2006;391(4):390-5.

29. Tiwary SK, Khanna R, Khanna AK. Transmural Migration Of Surgical Sponge Following Cholecystectomy: An Unusual Cause Of Gastric Outlet Obstruction. The Internet Journal of Surgery. 2005;7:2.

30. Ersoy H, Saygili OB, Yildirim T. Abdominal gossypiboma: ultrasonography and computerized tomography findings. Turk J Gastroenterol.2004;15(1):65-6.

31. Gencosmanoglu R, Inceoglu R. An unusual cause of small bowel obstruction: gossypiboma--case report. BMC Surg. 2003;3:6.

32. Puri SK, Panicker H, Narang P, Chaudhary A. Spontaneous transmural migration of a retained surgical sponge into the intestinal lumen-a rare cause of Intestinal obstruction. Indian Journal of Radiology and Imaging. 2002;12(1):137.

33. Manikyam SR, Gupta V, Gupta R, Gupta NM. Retained surgical sponge presenting as a gastric outlet obstruction and duodenoileo-colic fistula: report of a case. Surg Today. 20 02;32(5):426-8.

34. Dux M, Ganten M, Lubienski A, Grenacher L. Retained surgical sponge with migration into the duodenum and persistent duodenal fistula. Eur Radiol. 2002;12 Suppl 3:S74-7.

35. Rajesh R, Dalip DS, Anupam J, Jaisiram A. Effectiveness of puncture-aspiration-injection-reaspiration in the treatment of hepatic hydatid cysts. Iran J Radiol. 2013;10(2):68-73. 